\title{
Taxation and Budget Reform Commission (TBRC) Statutory Recommendation: Residential Property Assessment for Storm Hardening Improvement and Installation of Renewable Energy Source Devices ${ }^{1}$
}

Rodney L. Clouser²

A series of 16 fact sheets has been written on statutory and constitutional proposals adopted by the Taxation and Budget Reform Commission (TBRC). The publications in this series can be accessed at http://edis.ifas.ufl.edu. Fact sheets FE733 through FE741 address statutory changes and fact sheets FE742 through FE748 address constitutional amendments. These fact sheets should not be considered as an all-inclusive assessment of the statutory or constitutional changes recommended by the Taxation and Budget Reform Commission. Some details of proposed changes may not have been discussed due to space limitations. These fact sheets are not intended as a replacement for personal knowledge about actual or proposed changes but are a guide to inform the public on the issues.

\section{Introduction}

The Taxation and Budget Reform Commission (TBRC) has made a statutory recommendation to the Florida Legislature concerning "Residential Property Assessment for Storm Hardening Improvements and
Installation of Renewable Energy Source Devices." The recommendation proposes a state statute to implement a proposed constitutional amendment that will be recommended by the TBRC. The proposed constitutional amendment, if passed by Florida voters, would prohibit storm hardening devices and renewable energy devices from being considered in determining the assessed value of residential property.

\section{Storm Hardening Improvements and Renewable Energy Source Devices}

The TBRC defines storm hardening improvements as improving the strength of the roof deck attachment, creation of a secondary water barrier to prevent intrusion, hurricane-resistant shingles, gable-end bracing, reinforced roof-to-wall connections, storm shutters, impact-resistant glazing, and hurricane-resistant doors. Under the current statute, it is presumed that installation of these improvements would increase the assessed value of a residential property and, hence, taxes owed. The

1. This is EDIS document FE734, a publication of the Food and Resource Economics Department, Florida Cooperative Extension Service, Institute of Food and Agricultural Sciences, University of Florida, Gainesville, FL. Published July 2008. Please visit the EDIS website at http://edis.ifas.ufl.edu.

2. Rodney L. Clouser, professor and extension public policy specialist of the Food and Resource Economics Department, Florida Cooperative Extension Service, Institute of Food and Agricultural Sciences, University of Florida, Gainesville, FL.

The Institute of Food and Agricultural Sciences (IFAS) is an Equal Opportunity Institution authorized to provide research, educational information and other services only to individuals and institutions that function with non-discrimination with respect to race, creed, color, religion, age, disability, sex, sexual orientation, marital status, national origin, political opinions or affiliations. U.S. Department of Agriculture, Cooperative Extension Service, University of Florida, IFAS, Florida A. \& M. University Cooperative Extension Program, and Boards of County Commissioners Cooperating. Larry Arrington, Dean 
enabling legislation for the proposed constitutional amendment would prevent installation of these devices from increasing the assessed value of the property. Likewise, the impact would be the same for renewable energy source devices.

According to staff analysis, the proposed recommendation applies only to retrofitted residential properties and not to new home construction. The recommendation by the TBRC specifically states that new construction retrofitted within one year after a certificate of occupancy would not be eligible for the suggested change in assessment. Additionally, the recommendation applies to all residential property and not just homesteaded residential properties. The suggested statutory change also recommends that, after a change in ownership, renewable energy devices or improvements for resistance to wind damage may be considered in determining assessed value. Since property taxes are a local source of revenue, rather than a state source of revenue, impacts would be felt by local units of government. The recommendation of the proposed statutory change passed the TBRC by a vote of 17-0.

\section{Impact of Proposed Statutory Change}

Based on the TBRC's recommended date of adoption, the estimated fiscal impact on local units of government has been estimated at $\$ 11.4$ million between 2009-2010 and 2011-2012. Unless local governments raise millage rates (tax rates per $\$ 1000$ of assessed value), to offset the decrease in assessed value of this proposed change, compared to current law, local governments would collect less in taxes over the three-year period.

Some people would contend that passage of both the statutory and constitutional changes would be an incentive for residential property owners to retrofit homes with these devices. This may also result in less damage from hurricanes and strong winds to these properties. The addition of these devices to residential property, if they do reduce damage from storms, could dampen future increases in residential property insurance rates. Likewise, installing energy saving devices could make residential properties more energy efficient and reduce energy costs to residential homeowners.
Staff analysis indicates that both the statutory and constitutionally proposed changes apply to a broad range of residential property, including rental homes and apartments, multiple homes owned by a single owner, vacation homes, and homesteaded property. Less tax revenue being collected from the recommended change, compared to current law, will most likely be a concern to local units of government, especially after revenue decreases, because of the property tax amendment that passed in January of 2008. Local governments will be concerned about providing local government services with a more restricted revenue base to pay for those services.

\section{Summary}

If the suggestions by the TBRC are passed by the Florida Legislature and signed by the Governor, residential property owners who invest in renewable energy devices or improvements for resistance to wind damage will not have those devices considered in determining the assessed value of the property. However, after a change in ownership, renewable energy devices or improvements for resistance to wind damage may be considered in determining assessed value. Over a three-year period, it is estimated that this would result in Florida residential property owners seeing a reduction in property taxes paid of $\$ 11.4$ million, or on average of something less than $\$ 50$ per taxpayer to those who have installed these devices.

Although the statutory recommendations have been made by the TBRC, and in some instances with specific dates to become effective, the Florida Legislature and the Governor are not bound to the effective dates or the recommendations. Before these recommendations become law, they require approval of both the Florida Senate and House, and approval by the Governor. Citizens interested in the specific recommendations will need to follow the progress of the issue through the legislative process.

Additionally, there is no time limit for action by the legislature on the TBRC recommendations and they can be introduced in any future legislative session after initial submission by the TBRC. 


\section{References}

Florida Taxation and Budget Reform

Commission. 2008. An act relating to the assessment

of residential property. TBRC, Tallahassee, FL

(April). http://www.floridatbrc.com/pdf/SR5C1.pdf

Florida Taxation and Budget Reform

Commission. 2008. CS/SR 5 Staff Analysis and

Economic Impact Statement. TBRC, Tallahassee, FL

(April).

http://www.floridatbrc.com/pdf/

SR5preSDAnalysis.pdf

Florida Taxation and Budget Reform

Commission. 2008. Transmittal letter. TBRC,

Tallahassee, FL (April).

http://www.floridatbrc.com/pdf/

$\underline{\text { TransmittalLtrSR53_18_08.pdf }}$ 